JOURNAL OF ENGINEERING SCIENCES

ЖУРНАЛ ІНЖЕНЕРНИХ НАУК

ЖУРНАЛ ИНЖЕНЕРНЫХ НАУК

Web site: http://jes.sumdu.edu.ua

DOI: $10.21272 /$ jes.2019.6(1).e4

Volume 6, Issue 1 (2019)

UDC 629.113

\title{
Optimum Choice of the Front Suspension of an Automobile
}

\author{
Belkhode P. N.
}

Laxminarayan Institute of Technology, R.T.M. Nagpur University, 440033 Nagpur, India

\section{Article info:}

Paper received:

The final version of the paper received:

Paper accepted online:
December 21, 2018

February 4, 2019

February 9, 2019
*Corresponding Author's Address:

pramodb@rediffmail.com

\begin{abstract}
The paper details the optimum choice of the front suspension of an automobile. The influence of suspension on the steering geometry is studied by considering the various combinations of joints at the four-bar mechanism of the front suspension. The purpose of the suspension is to make the job easier for the tires and give a predictable behavior so that the driver will have control of the car. The most common suspension used is double wishbone. The performance of the steering geometry depends upon the performance of various steering parameters such as kingpin angle, caster angle, camber angle, toe in and out and scrub radius. This steering geometry depends upon the position of kingpin axis an imaginary line passing through the knuckle pin. The steering geometry is a function of vehicle speed, link lengths, and road condition. The selection of the optimum choice of the suspension makes the benefit the comfort for driving and controlling the vehicle conditions.
\end{abstract}

Keywords: suspension, steering geometry, front suspension, optimum, mechanism.

\section{Introduction}

The suspension of the front wheels is more complicated than the suspension of the rear wheels. This is because the front wheels move up and down. Front suspension changes the orientation of wheel with respect to the road, affecting the steering behavior and tire. The most common suspension used is double wishbone. As this suspension locates the wheels and controls the geometry of their movement, over bumps. Unequal length wishbones are preferred because they separate the effects of the springs more effectively and controls wheel movement better. The upper wishbone is shorter than the lower one for superior camber control. Therefore, it is also called as SLA which stands for Short Long Arm. It is easily recognized that an SLA suspension is a three-dimensional four bar mechanism [1-2].

Ball joints provide key pivot points in the front independent suspension set up. In operation the swiveling action of the ball joints allows the wheel and spindle assemblies to be turned left or right and to move up and down with changes in road surface geometry. Four control arms are connected with spherical joints, lower ones and upper ones [3]. The other ends of these control arms are connected to the vehicle frame via revolute joints. Various types of mechanisms with two spherical pairs along with revolute pairs and cylindrical pairs were formed by changing the position of various joints [4].
These mechanisms are analyzed for the optimum choice of a front suspension. It also presents the steering geometry parameters along with the measuring techniques. This exercise can be looked upon as a type synthesis of suspension mechanism [5].

\section{Research Methodology}

\subsection{Steering geometry parameters}

Presently steering geometry parameters kingpin inclination angle, caster angle, camber angle, toe angle are measured using alignment equipment, caster / camber gauge, a set of turntable and bubble gauges. The steering wheel should be centered while measuring the steering performance. Turn the steering wheel completely to the right then turn the wheel completely to the left and count the number of turns of the steering wheel. After following the complete procedure steering geometry performance parameters are measured and adjusted.

On the basis of six included angles of the $3 \mathrm{D}$ front suspension mechanism, one at each revolute joints and two at each spherical joints of this four bar chain, the position of kingpin axis is determined. Steering performance depends on the position of a kingpin axis. Depending on the position of the kingpin axis, caster angle, camber angle, kingpin angle, and toe angle of the four-wheel vehicle are decided. 


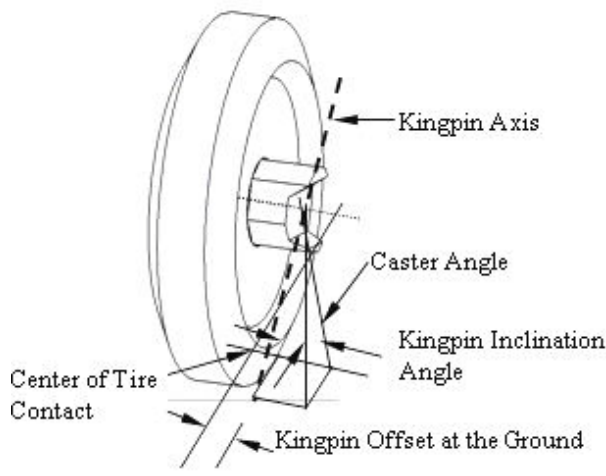

Figure 1 - Steering geometry parameters [6]

The position of the kingpin axis is determined using the Denavit Hartenberg Principle [6-7].

Joint $\mathrm{O} 1$ and $\mathrm{O} 2$ are revolute joints and joints $\mathrm{A}$ and $\mathrm{B}$ are Spherical joints as shown in Figure 2. The relative orientation of two links connected at je joint can be decided in terms of magnitudes of included angles which in turn can be measured by the potentiometer and associated electronic instrumentation [8].

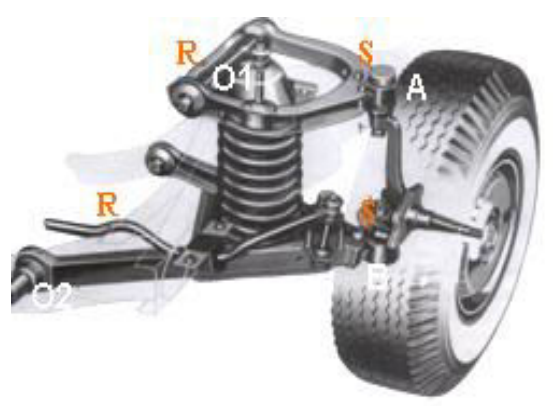

Figure 2 - The front suspension of an automobile (A-arm front suspension) [6]

\subsection{Selection of the "Revolute-Spherical- Sherical-Revolute" mechanism}

The front suspension is a three-dimensional four-bar mechanism having four control arms. These arms are connected with four joints, lower ones, and upper ones. Various types of mechanisms with two spherical pairs along with revolute pairs and cylindrical pairs were formed by changing the position of various joints for linear motion and rotational motion. Linear and rotational motion completely defines the relative position of the control arms. Table 1 shows the formulation of various combinations of mechanisms by changing the joints, where S - "spherical", R - "revolute", C - "cylindrical" signs; $\mathrm{X}$ indicates that motion is restricted in columns 2 , 3 and 5, whereas $X$ indicates in column 4 that motion is permitted.

The analysis of different combinations of mechanism is done by the Denavit Hartenberg notation [9-11]. The analysis of RSSR, RRSS, and SRRS out of 24 mechanisms of table 1 is shown below [12-14].
Table 1 - Formulation of various combinations of mechanisms

\begin{tabular}{|c|c|c|c|c|}
\hline $\begin{array}{c}\text { Type } \\
\text { synthesis } \\
\text { of O1-A- } \\
\text { B-O2 } \\
(1-2-3-4)\end{array}$ & $\begin{array}{c}\text { Rotation } \\
\text { of } \\
\text { knuckle } \\
\text { link }\end{array}$ & $\begin{array}{c}\text { Vertical } \\
\text { movement } \\
\text { of knuck- } \\
\text { le link }\end{array}$ & $\begin{array}{c}\text { Motion of } \\
\text { upper and } \\
\text { lower } \\
\text { arms in Y } \\
\text { direction }\end{array}$ & $\begin{array}{c}\text { Motion of } \\
\text { both arms } \\
\text { O1-A and } \\
\text { O2-B due } \\
\text { to link } \\
\text { AB }\end{array}$ \\
\hline SSCR & - & - & $\times$ & - \\
\hline SSRC & $\times$ & - & $\times$ & - \\
\hline CSSR & - & - & - & - \\
\hline RSSC & - & - & - & - \\
\hline CRSS & $\times$ & $\times$ & $\times$ & - \\
\hline RCSS & - & - & $\times$ & - \\
\hline SCRS & $\times$ & $\times$ & $\times$ & - \\
\hline SRCS & $\times$ & $\times$ & $\times$ & - \\
\hline SSRR & $\times$ & $\times$ & $\times$ & - \\
\hline RSSR & - & - & - & - \\
\hline RRSS & $\times$ & $\times$ & $\times$ & - \\
\hline SRRS & $\times$ & $\times$ & $\times$ & - \\
\hline SSCC & - & - & $\times$ & - \\
\hline CSSC & - & - & - & - \\
\hline CCSS & - & - & $\times$ & - \\
\hline SCCS & - & - & $\times$ & $\times$ \\
\hline RSSS & - & - & $\times$ & - \\
\hline SRSS & $\times$ & $\times$ & $\times$ & - \\
\hline SSRS & $\times$ & $\times$ & $\times$ & - \\
\hline SSSR & - & - & $\times$ & - \\
\hline CSSS & - & - & $\times$ & - \\
\hline SCSS & - & - & $\times$ & - \\
\hline SSCS & - & - & $\times$ & - \\
\hline SSSC & - & - & $\times$ & - \\
\hline
\end{tabular}

\section{Results}

The design schemes proposed in the research [6] are presented in Figures 3-5 and described below.

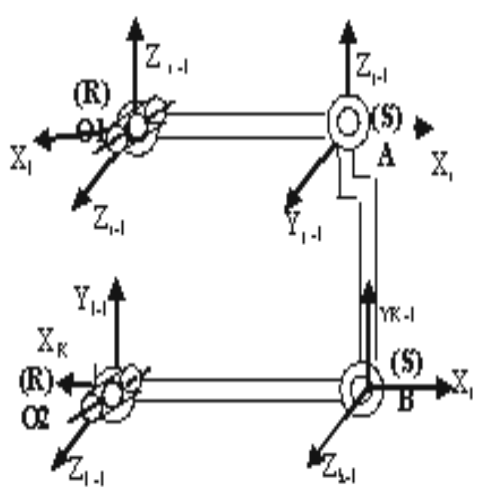

Figure 3 - RSSR ("Revolute-Spherical-Spherical-Revolute”) 
1. Rotation of link AB is free to rotate about the vertical axis in the clockwise and anticlockwise directions. This makes steering easy. Therefore $\mathrm{X}$ is not marked in column 2 of Table 1 as motion is not restricted.

2. Vertical movement of knuckle link $A B$ is possible. Since joint $A$ and joint $B$ is spherical joints. Therefore $X$ is not marked in column 3 of Table 1 for not restricted motion.

3. Since the joint $\mathrm{O} 1$ and joint $\mathrm{O} 2$ are revolute joints, motion in $\mathrm{Y}$ direction of upper arm O1-A and motion of lower arm O2-B is restricted. Therefore $\mathrm{X}$ is not marked in column 4 of Table 1 for restricted motion.

4. Upper arm O1A and lower arm O2-B are moved by motion getting from link $A B$. Therefore $X$ is not marked in column 5 of Table 1 as motion is not restricted [15].

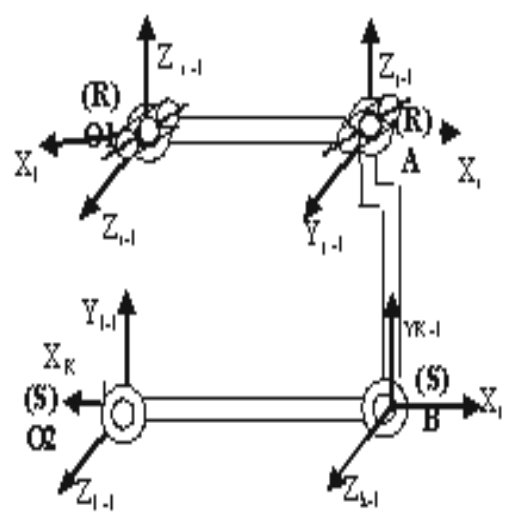

Figure 4 - RRSS ("Revolute-Revolute-Spherical-Spherical”)

1. Rotation of link $\mathrm{AB}$ is not free to rotate about the vertical axis in the clockwise and anticlockwise directions. This makes steering difficult. Therefore $\mathrm{X}$ is marked in column 2 of Table 1 as motion is restricted.

2. Vertical movement of knuckle link AB is not possible. Since joint A is revolute joint and joint B is spherical. Therefore $\mathrm{X}$ is marked in column 3 of Table 1 for restricted motion.

3. Since the joint $\mathrm{O} 1$ is revolute and joint $\mathrm{O} 2$ is spherical Joint, motion in the $\mathrm{Y}$ direction of upper arm O1-A is restricted whereas the motion of lower arm O2-B is permitted. Therefore $\mathrm{X}$ is marked in column 4 of Table 1 for permitted motion.

4. Upper arm O1A and lower arm O2B are moved by motion getting from link $\mathrm{AB}$. Therefore $\mathrm{X}$ is not marked in column 5 of Table 1 as motion is not restricted.

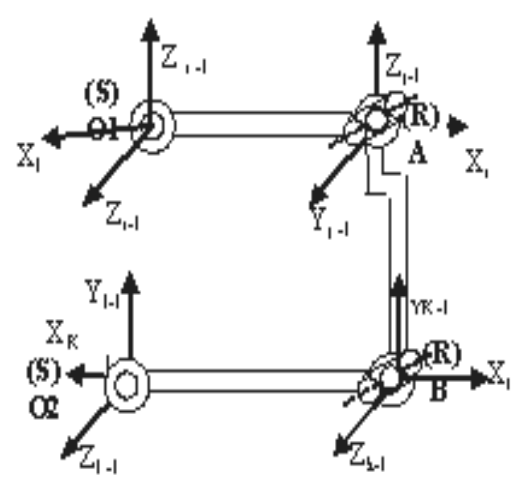

Figure 5-SRRS (“Spherical-Revolute-Revolute-Spherical”)

1. Rotation of link AB is not free to rotate about vertical axis in clockwise and anticlockwise direction. This makes steering difficult. Therefore $\mathrm{X}$ is marked in column 2 of Table 1 as motion is restricted.

2. Vertical movement of knuckle link $A B$ is not possible. Since joint A and joint B is the revolute joint. Therefore $\mathrm{X}$ is marked in column 3 of Table 1 for restricted motion.

3. Since the joint $\mathrm{O} 1$ and joint $\mathrm{O} 2$ are spherical joints, motion in the $\mathrm{Y}$ direction of upper arm O1-A and motion of lower arm O2-B is permitted. Therefore $\mathrm{X}$ is marked in column 4 of Table 1 for permitted motion.

4. Upper arm O1A and lower arm O2-B are moved by motion getting from link $\mathrm{AB}$. Therefore $\mathrm{X}$ is not marked in column 5 of Table 1 as motion is not restricted.

\section{Conclusions}

The complete analysis of these 24 combinations of mechanisms concluded that four types CSSR, RSSC, RSSR, and CSSC are usually selected. From the safety and maintenance point of view CSSR, RSSC and CSSC are avoided due to axial movement of cylindrical joints. Finally, the RSSR ("Revolute-Spherical-SphericalRevolute") is considered to be the best for giving the complete motion performed by the suspension.

\section{Acknowledgments}

The author sincerely thank Professor Dr. J. P. Modak, Ex-Professor VNIT, Nagpur, and Dean (R\&D), PCE, Nagpur for discussion and reading during manuscript preparation.

\section{References}

1. Belkhode, P. N. (2017). Mathematical Modelling of Liner Piston Maintenance Activity using Field data to Minimize Overhauling Time and Human Energy Consumption. Journal of the Institution of Engineers, Series C, Springer Publication, pp. 1-9.

2. Belkhode, P. N., \& Vidyasagar, V. (2014). Mathematical Model for Face Drilling in underground mining operation. IJERST International Journal of Engineering Research and Science Technology, Vol. 3(2).

3. Belkhode, P. N., \& Borkar, K. (2013). Modelling and Analysis of Overhauling of Crankshaft in Locoshed. International Journal of Engineering Research and Technology. ESRSA Publication, Vol. 2(11).

4. Belkhode, P. N., \& Borkar, K. (2014). Maintenance Activity for Locomotive Crankshaft by using FDBM Approach for Saving the Resources. International Journal of Engineering and Technical Research, ER Publications, Vol. 2(9). 
5. Gillespie, T. D. (1992). Fundamentals of Vehicle Dynamics. Society of Automotive Engineers, Warrendale Inc., PA.

6. Suh, \& Redcliff (1978). Kinematics Design of Mechanisms, John Wiley \& Sons, New York.

7. Denavit, \& Hertenberg (1955). A Kinematic Notation for Lower Pair Mechanisms Based on Matrices. ASME Transaction, Journal of Applied Mechanics, pp. 215-221.

8. Rill, G. (2007). Vehicle Dynamics. Fachhochschule Regensburg, University of Applied Sciences, Hochschule for Technik Wrtschaft Soziales.

9. Fu, K. S., Gonzalez, R. C., \& Lee, C. C. G. (1987). Robotics: Control Sensing, Vision and Intelligence. Mc Graw Hill Internation Edition, Signapore.

10. Lin, P. D., \& Hsich, J. F. (2007). A New Method to Analyze Spatial Binary Mechanism with Spherical Pairs. Journal of Mechanical Design, Vol. 129, pp. 455-458.

11. Gao, J., Case, K. W., \& Magle, S. P. (1995). General 3D-Tolerance Analysis of Mechanical Assemblies with small Kinematic Adjustments. ADCATS Report No. 94-2.

12. Tao, D. C. (1964). Applied Linkage Synthesis. Addison-Wesley Publishing Company Inc., London.

13. Theander, A. (2004). Design of a Suspension for a Formula Student Race Car, Vehicle Dynamics Aeronautical and Vehicle Engineering. Royal Institute of Technology, Sweden.

14. Singh, K. (2003). Automobile Engineering. Standard Publishers Distributors, Delhi.

15. Ramalingam, K. K. Automobile Engineering - Theory and Practice. SciTech Publications, Pvt. Ltd., Chennai, India.

\title{
Оптимальний вибір передньої підвіски автомобіля
}

\author{
Белходе П. Н.
}

Лаксмінарайський технологічний інститут, Університет м. Нагпур, 440033, м. Нагпур, Індія

Анотація. У статті розглядається процедура вибору оптимальної геометрії передньої підвіски автомобіля. Досліджується вплив підвіски на геометрію керма 3 урахуванням різних комбінацій шарнірів чотирьохбалкового механізму передньої підвіски. Метою підвіски є полегшення роботи шин і надання передбачуваної поведінки для того, щоб водій мав контроль над автомобілем. Найбільш уживаною підвіскою $\epsilon$ подвійна поперечина. Ефективність геометрії керма залежить від виконання різних параметрів керування, таких як кут зчеплення, кут конуса, кут розвалу, тощо. Ця геометрія керма залежить від положення осі шпильки як уявної лінії, що проходить крізь штифт. Геометрія рульового керування є функцією швидкості транспортного засобу, довжини ланки та стану доріг, тому вибір оптимального вибору підвіски надає перевагу комфорту для керування та контролю умов використання автомобіля.

Ключові слова: підвіска, геометрія керма, передня підвіска, оптимум, механізм. 